УДК 330.34

DOI: $10.14451 / 1.191 .150$

\title{
ИННОВАЦИОННОЕ СОЦИАЛЬНО-ЭКОНОМИЧЕСКОЕ РАЗВИТИЕ И УПРАВЛЕНИЕ ЧЕЛОВЕЧЕСКИМ КАПИТАЛОМ: ЧЕЛОВЕК КАК ГЛОБАЛЬНАЯ ЦЕННОСТЬ
}

\author{
(c) 2020 Поповский Юрий Николаевич \\ соискатель \\ ФГУП «ВНИИ «Центр», Россия, Москва \\ E-mail: agor80@yandex.ru
}

(c) 2020 Семенова Валерия Валерьевна

кандидат экономических наук, доцент, доцент Центра проектной деятельности

Московский политехнический университет, Россия, Москва

E-mail: alisavalera@rambler.ru

\author{
(C) 2020 Шурукова Елена Евгеньевна \\ аспирант \\ ИПУ РАН, Россия, Москва \\ E-mail: agor80@yandex.ru
}

В статье рассматривается эволюция социальных ценностей общества, взаимосвязь прав человека и основных социальных ценностей, влияние становления социальных процессов на развитие экономики и экономических отношений, влияние развития человеческого капитала на развитие общества, ценность человека и его жизни как одной из основопологаюших ценностей современного мирового сообщества и главного ресурса формирования человеческого капитала.

Ключевые слова: социальные права, человеческий капитал, социальная ценность, экономическое развитие, экономический кризис, гуманитарные технологии, ценность жизни, социально-экономическое развитие.

Эволюция человеческого общества напрямую связана с отношением человека к человеку. С определенной долей уверенности можно утверждать, что именно изменения отношения человека к подобному себе лежат в основе исторической смены организации общества, начиная с первобытнообщинного строя и, заканчивая современной государственной организацией большинства ведущих стран и экономик мира. Государственная (социальная) демократия является продвинутой формой организации государственной власти, по мнению многих современных политиков, социологов, экономистов, общественных деятелей. Государственная власть (она же обладает и экономической властью) определяет основные социальные ценности, осуществляет контроль над процессом производства и распределения благ. Начиная с первых попыток государствообразования, человечество решало вопрос о правах человека в обществе. Постепенно с развитием государства как социального института многие права превратились в социальные ценности, которые определяют имидж государства, приоритет его стратегического развития и определяют многие важные социально-экономические показатели, такие как уровень доходов, качество жизни, прозрачность принимаемых властью решений, а так же имеют конституционную и законодательную силу, накладывая социально-экономические обязанности на человека как на гражданина и определяя его права [3, 7]. Основными характеристиками любой общественной формации является экономическая и политическая организация общества, так как экономика определяет общественное производство и распределение благ, а политика определяет власть, и, следовательно, определяет основные права (ценности) и обязанности членов общества, а так же правила распределения общественных благ [2, 5]. Вспомним известный тезис К. Маркса, что «бытие определяет сознание». Если определить «бытие» как политическое и экономическое развитие социума, а «сознание» как коллективное сознание членов социума, то получается, что человечество проделало сложный путь от отрицания ценности 
человеческой жизни, через признание ценности человеческой жизни нормой для общества, до возведения этой ценности в рамки смылообразующих общественных ценностей и ориентиров стратегического развития. Влияние экономических процессов на политические, и воздействие политических процессов на экономические это основа функционирования любого общества и причина потребности в инновационном развитии социально - экономических процессов. «В результате перехода к производящей экономике начали появляться многочисленные цивилизации. Прогрессивные формы земледелия вели к усложнению организации производства, появлению новых управленческих, организационных функций и к необходимости регламентировать производство, хранение и распределение прибавочного продукта. Появилась необходимость учитывать трудовой вклад каждого члена общества» [1]. Каждая следующая социально - экономическая формация, развиваясь, переходила от отношения к человеку как к трудовому ресурсу в сторону признания его гражданских прав, личной уникальности, права на жизнь и свободу, и т.д. Социальные ценности и приоритеты социального устройства общества эволюционно развивались вместе с общественными социально-экономическими процессами, постепенно становясь нормами, затем обретая статус права и закона в современном обществе, продолжая развитие социально - значимых процессов в сторону преобладания гуманистических ценностей современного мирового сообщества.

Но, прежде чем овладеть общественным сознанием и стать предметом законодательного регулирования, идея прав человека должна была возникнуть на уровне теории. Для этого необходимы соответствующие социальные, экономические и политические предпосылки. Первобытно общинный строй как первая форма общественно - экономической формации рассматривается в современной теории государства и права как не государственная организация общества, поэтому сложно выделять и рассматривать социальные ценности и нормы такого общества. Возникновение рабовладельческого строя некоторые ученые связывают с первой экологической проблемой человечества: истощение земельных (плодородных) ресурсов при одновременном росте населения. (Имеет место мнение ученых о том, что некоторые пустыни, в частности Сахара, имеют рукотворное происхождение и ранее на их месте были плодородные земли) [9]. Борьба за выживание в условиях, когда экономика базировалась на земледелии и ручном труде ремесленников, определяя уязвимость бытия (зависимость от погодных условий, отсутствие освещенности с ночное время и т.д.) не давала возможности формироваться социальным ценностям гуманистической направленности в обществе, поэтому ценность человеческой жизни не рассматривалась, как ценность, на сохранение которой направлены усилия власти.

Эволюционное развитие человечества связано с развитием научно-технического прогресса, с повышением возможностей человека не зависеть от условий окружающей среды и даже противостоять им [6, 8]. К важным факторам социального развития следует отнести возможность продуцирования, хранения и передачи знания, которое стало более доступным с изобретением печатного станка. Развитие научнотехнического прогресса и промышленные революции, повышение роли человека в общественном производстве материальных благ, повысило роль человека в экономике и политике. Развитие машинного производства и технологий сделало развитие общества менее зависимым от капризов окружающей среды. С повышением качества жизни, человек стал предъявлять более высокие требования к организации социальных и общественных процессов.

Взаимозависимость экономических и политических процессов - основа функционирования любого общества и сегодня. Благодаря эволюции взаимосвязи экономики и политики современная управление имеет несколько стилей управления, начиная от авторитарного, в основе которого подавление воли подчиненного, принуждение и превосходство человека над человеком по различным социально - биологическим признакам (цвет кожи, раса, иерархия и т.д.), до социального лидерства, которое подразумевает сотрудничество « на равных» для достижения благосостояния и процветания общества [4]. Ценность жизни как социальной ценности отсутствовала, как таковая, если рассматривать рабовладельческий строй. Протекание социально-экономических процессов во все времена зависело от формы власти в обществе, а форма власти зависел от признаваемых прав и обязанностей человека (гражданина), а так же от социальных стереотипов представления об- 
щества о справедливости, которые имеют как вербальную, так и невербальную форму воздействия и проявления, присутствуя в виде национальной культуры, традиций, ритуалов и т.д.

Чаще всего основные характеристики того или иного строя как формы организации общества составляют показатели развития экономики. Если рассматривать ценность человеческой жизни как социальную ценность, которая с эволюционным развитием общества становится смыслообразующей, то стоит заметить, что отношение человека к человеку становятся более гуманными с переходом в рамках исторической последовательности от строя к строю. Экономика каждого следующего строя также имела более высокие показатели благодаря развитию науки и техники. Н. Бердяев писал, что «человек - есть высшая ценность и именно эта глобальная ценность позволяет обществу интегрироваться нечто цельное».

Одним из главных достижений современного общества является его гуманистическая направленность, то есть основной ценностью общества является человек. «Человек - это звучит гордо» - писал М Горький, в своей пьесе «На дне». На сегодняшний день, можно сказать, что это центральный лозунг всех стран, заботящихся о своем будущем: уровне жизни, уровне социальной защищенности, соблюдении прав человека, экологии, экономическом развитии и т.д. Гуманистическая направленность в управлении началась с развитие гуманистической школы управления, с 1930-1950 г. Все современные технологи управления испытывают на себе позитивное влияние этой школы, направленное на учет особенностей работника как уникальной личности, имеющей индивидуальные особенности, потребности, интересы, личные цели, а так же являющейся основной формирования и развития человеческого капитала.

Гуманистическая направленность общества развивается и сегодня, определяя инновационное экономическое развитие. Развитие происходит, главным образом, посредством влияния гуманистических ценностей на социально экономические процессы. Примером, таких процессов, могут служить: отмена смертной казни, эмансипация, социальные программы для малообеспеченных и неимущих, развитие толерантности, устранение различий по расовой и национальной принадлежности, инновационные технологии медицины, развитие зеленой эконо- мики и зеленых технологий и т.д.

Инновационное экономическое развитие современного общества определяется потребностью человека и уважением к праву удовлетворения этой потребности, как социумом, так и экономикой. Однако, развитие социума (общества) возможно только при условии развития и эффективного использования человеческого капитала, который является источником инновационных технологий, идей, решений, источником и носителем, которого является человек. Если жизнь - основная социальная ценность, то человеческий капитал - это основной ресурс удовлетворения жизненоважных потребностей. Термин «человеческий капитал» был введен в экономическую науку Теодором Шульцем в 1961. Т.Шульц определял человеческий капитал как совокупность знаний и навыков работников, которая представляет собой экономическую ценность и увеличивает производительность труда. Современное представление о составляющих человеческого капитала шире, к составляющим человеческого капитала относят не только знания и навыки, но и врожденные способности, и полученный опыт.

От качества человеческого капитала зависят многие показатели развития современного общества, среди этих показателей разработка и внедрение инноваций, экология сознания, уровень жизни, развитие социальных программ, состояние национальной экономики и т.д. Человеческий капитал, в свою очередь, как «коллективное знание» зависит от многих социальноэкономических факторов, таких как уровень, качество и доступность образования, изменения и регулирование рынка труда, экономические и политические кризисы и т.д. Одно из самых негативных воздействий на человеческий капитал оказывают экономические кризисы, которые, как правило, влекут за собой изменения рынка труда, инфляцию и снижение доходов населения, что в свою очередь приводит к оскудению социальной сферы (рост цен на образование и медицинские услуги, сокращение финансирования социальных программ и т.д.). Так как Россия последние десятилетия подвержена социально - экономическим реформам и постоянным изменениям функционирования внутренних социально - экономических систем и процессов, которые можно приравнять к внутренним кризисным явлениям, то Россия в рейтинге по индексу развития человеческого капитала (Human 
Capital Index), согласно исследованиям аналитической группы Всемирного экономического форума (ВЭФ) в сотрудничестве с Гарвардским университетом (Harvard University) и международной консалтинговой компанией Mercer Human Resource Consulting занимает 52-е место среди 122-х экономик (стран мира). Уровень человеческого развития (Human Development Index), который представляет собой комбинированный показатель, характеризующий развитие человека в странах и регионах мира, который выпускается Программой развития Организации Объединённых Наций (ПРООН), так же свидетельствует о социально- экономических проблемах России, в 2019 по этому показателю Россия заняла 49-е место [10]. В 1990 году ПРООН опубликовала первый доклад с оценкой экономического и социального прогресса стран мира, в котором было сформулировано понятие человеческого развития: «Развитие человека является процессом расширения спектра выбора. Наиболее важные элементы выбора - жить долгой и здоровой жизнью, получить образование и иметь достойный уровень жизни. Дополнительные элементы выбора включают в себя политическую свободу, гарантированные права человека и самоуважение» [11]. Все элементы выбора ПРООН человеческого развития представляют собой универсальные социально-экономические ценности современного общества, которые определяют направления социального развития мировой цивилизации. Инновации в области цифровых технологий повлияли на глобализацию многих социально - экономических процессов и ценностей, так как изменись условия социально - технологической среды, в которой они формируются. В 2010 году было уточнено определение человеческого развития: «Развитие человека представляет собой процесс расширения свободы людей жить долгой, здоровой и творческой жизнью, на осуществление других целей, которые, по их мнению, обладают ценностью; активно участвовать в обеспечении справедливости и устойчивости развития на планете». Ценность человека и создание условий для ее сохранности и развития было признано глобальной ценностью современного мирового социально-экономического развития. Таким образом, в основу индекса человеческого развития положены три основные составляющие, которые имеют свои индексы измерения:

1. Благосостояние: расширение реальных свобод человека таким образом, чтобы люди и общество в целом могли процветать - Индекс ожидаемой продолжительности жизни. (По показателю этого индекса (2019 г.) Россия находится на 109-м месте. Средняя продолжительностью жизни 72-а года.)

2. Права, возможности, агентность: возможность людей и групп действовать и получать ценные результаты.- Индекс образования. (По показателю этого индекса (2019г) Россия находится на 33-м месте

3. Справедливость: повышение социальной справедливости и уважение прав человека, а также обеспечение устойчивости полученных результатов во времени.- Индекс валового национального дохода на душу населения. (По показателю этого индекса (2019 г.) Россия занимает 65-е место, уступая Польше, Португалии, Венгрии).

Стоит отметить, что индекс валового национального дохода часто понимается как индекс уровня жизни, поэтому является важной характеристикой, как экономического состояния государства, так и соблюдения социальных норм и ценностей в этом государстве. Страны, с высоким индексом показателя человеческого капитала (Дания, Германия, Швеция) как правило, имеют высокие показатели индекса человеческого развития и индекса человеческого капитала, экономика этих стран обладает стабильностью, то есть может «обеспечить устойчивость полученных результатов во времени». Развитие человеческого капитала обуславливает развитие экономики - экономики, которая может обеспечить достойное существование человека, то есть способной создать условия для «расширения реальных свобод человека таким образом, чтобы люди и общество в целом могли процветать». Следовательно, человек как личность и человек как источник человеческого капитала, от качества, которого зависит развитие мировой цивилизации, является глобальной ценностью.

\section{Библиографический список}

1. Головистикова А. Н. Права человека. Учебник, Изд-во «Эсмо», 2008 г.

2. Горохова А.Е. Факторы развития промышленных предприятий в условиях становления постиндустриальной экономики // Экономика и предпринимательство. 2014. № 12-2 (53). С. 870-873 
3. Ефремов А.А., Щербаков В.В.Инвариантность сетевых форм организации логистических цепей // Вестник Астраханского государственного технического университета. Серия: Экономика. 2011. № 2. С. 72-79

4. Ефремов А.А. Лизинговые отношения в формировании цепей поставок // Проблемы современной экономики. 2011. № 1 (37). С. 145-148

5. Секерин В.Д., Горохова А.Е. Инновационная среда как фактор эффективности коммерциализации инноваций // Известия Московского государственного технического университета МАМИ. 2014. Т. 5. № 2 (20). С. 39-43

6. Секерин В.Д., ГороховаА.Е., ЛаптеваД.Я., Калинкина Т.М.Научно-техническая информация как фактор развития общества // Известия МГТУ «МАМИ».-2013. № 1 (15), т.5.- С. 136-141

7. Семенова В.В., Шурукова Е.Е., Гасанбеков С.К. Социально-экономическое развитие: социальный стресс и адаптация как технология управления развитием // Финансовая экономика, 2020. - № 7(2). - C. 182-184

8. Danko T.P., Ekimova K. V., Bolvachev A. I., Zarova E. V., Shemetkova O. L., Solovyova M. G., Sekerin V.D. ASSESSMENT OF THE COMPETITIVE POTENTIAL OF THE REGION THROUGH AN INTEGRATED SYSTEM OF RATING POSITIONING // International Journal of Economic Research. 2016. T. 13. № 6. C. 2361-2367

9. David K. Wright Human as Agents in the Termination of the African Humid Period, Frontiers in Earth Science, (2017) DOI: 10.3389/feart.2017.00004

10. https://gtmarket.ru/ratings/human-development-index - обращение 01.09.2020 г.

11. https://www.ohchr.org/RU/Pages/Home.aspx - обращение 03.09.2020 г. 